\title{
3 The Reuse of Buildings: Libraries Behaving Sustainably
}

\begin{abstract}
The chapter takes a broad overview starting from the premise that reuse of buildings has obvious benefits in terms of recycling materials and retaining the embodied energy contained within the structure. It focuses on the opportunity for libraries to adopt a fully sustainable approach by locating in existing buildings in need of a new use which has the added advantage of creating a sense of place and community identity. Examples of old buildings that have been brought back into use as libraries are discussed as are the challenges of sensitively adapting listed buildings and blending old and new elements respectfully and imaginatively. Most of the examples discussed are drawn from the United Kingdom and Ireland although reference is made to other worldwide examples.
\end{abstract}

Keywords: Library buildings; Buildings - Remodelling for other use; Sustainability; Library buildings - United Kingdom

\section{Introduction}

Sustainability, it could be argued, is nothing new. Indeed, in the stimulating and exciting world of library design, sustainability is very much part of any discussion. The question to ask is, however, has the awareness of what sustainability constitutes been misplaced? In the quest for energy-efficient, environmentally friendly new buildings, is there a failure to recognise the legacy and value of old and historic buildings? Historic buildings are valuable because they are beautiful, rare, indeed often unique, and because they tell the story of the world's towns and cultures. What could be more sustainable than keeping buildings with the embodied energy existing within them, not to mention the skill and effort involved in constructing them in the first place. All the energy contained in a building, that is the energy used to produce the materials which make up the building, is wasted if the structure is demolished. None of this energy is wasted if the building is reused. An English Heritage report pointed out that the energy used in the construction of a typical Victorian terrace house is equivalent to the amount of energy that could drive a car five times round the earth (English Heritage 2004). Retaining and reusing existing building stock prevents that energy from being wasted.

Ә Open Access. (2021 Karen Latimer, published by De Gruyter. (c) BY-NC-ND This work is licensed under the Creative Commons Attribution-NonCommercial-NoDerivatives 4.0 International License. 
Of course new buildings are needed but careful thought is also needed about their impact and the ever-increasing demands they put on an already overloaded infrastructure. Simon Sturgis, Chairman of the UK Royal Institute of British Architects Sustainability Group, has commented that, "The connection needs to be made between the climate emergency and all-glass buildings. But the connection hasn't been made yet" (Tapper 2019). Glass is not the only building material causing concern. Concrete is now widely recognised as highly damaging to the environment. Some recent figures which might help to focus the mind are as follows:

- Approximately 8\% of global $\mathrm{CO}_{2}$ comes from concrete production (Watts 2019);

- $\quad 10 \%$ of all industrial water use goes to making concrete (Watts 2019);

- Every hour the global concrete industry pours enough to fill the Albert Hall in London four times over (Watts 2019);

- Concrete entombs fertile soil and biodiverse habitats (Watts 2019);

- "The design, construction, occupation, maintenance and demolition of the world's built environment consumes about $50 \%$ of all the raw materials annually. In the UK we consume over 600 million tonnes of new products every year and generate over 200 tonnes of waste; 125 million tonnes of this is construction waste. Our industry creates $45 \%$ of $\mathrm{UK} \mathrm{CO}_{2}$ emissions" (Baker-Brown 2019).

As people dutifully recycle paper and plastic, glass bottles and aerosol cans and indeed building materials, they should reflect on the even greater impact of recycling buildings.

\section{A Future for the Past}

The architectural historian Nikolaus Pevsner was a great believer in the importance of architecture as it is all around, needing only to be noticed. The journalist Rachel Cooke commenting on recent listings of historic buildings by Historic England noted that when one looks at such buildings, "not only does the sweep of history wash over you in an invigorating wave; you picture, too, all those individuals, communities and experts who have campaigned long and hard for their cherished lido or lychgate to be protected and somehow it gives you hope." She goes on to say, "The more we look, the more we see; the more we see, the happier we feel. Gaze only at the pavement and it will do your soul no good at all" (Cooke 2019, 57). She could easily have added libraries to her list, and indeed does mention them in her article. The subject of wellbeing and libraries is for another 
book, but it is worth noting the connection between a sense of place, mental health and identity in the sustainability argument. The novelist, Ralph Ellison, has been credited with saying that if you do not know where you are you do not know who you are. Increasingly nowadays there is a growing awareness of the need to live sustainably and to preserve community identity, part and parcel of which is the need to retain architectural distinctiveness. Historic buildings shape individuals' memories and their sense of belonging.

The close link between community and sustainability has been starkly highlighted in recent studies on the demise of the High Street in the UK and the similar challenges of revitalising the Main Street in America. As shopping streets and town centres decline, there will be no shortage of buildings in search of new uses. Too often the solution to reviving a seemingly failing urban area is to build something big and bold such as a new leisure centre, sports arena or retail complex. Rather than necessarily being the shining beacons of a bright new future, these wonders can all too soon become less shiny white elephants as the wheel of fashion moves on to the next big thing. Small, too, can be powerful. Areas with older, smaller buildings are often more dynamic, diverse and lively than those with large new buildings. Authenticity matters in today's complex world. The value of uniqueness should not be ignored nor should the environmental, psychological and social power of historic assets. In the early sixties the American architectural journalist, Jane Jacobs, wrote a searing attack on the then current ideas about city planning and rebuilding in her book The Death and Life of Great American Cities (Jacobs 1961). She argued that large scale demolition and replacement of older, smaller buildings with large new structures drains the life and vitality from urban neighbourhoods. Much of what she said is as relevant today as it was when first written and it is an argument used powerfully by the team at Main Street America.

Ed McMahon, Chairman of Main Street America and Senior Fellow for Sustainable Development at the Urban Land Institute Washington DC, speaking at the 2019 Heritage Trust Network conference in Derry, Northern Ireland, said:

It is a mistake to think that economic revival is always about "the one big thing." America's communities are littered with projects that were sold as the "silver bullet" solution to a city's economic woes. Whether it was a festival marketplace, a convention center, a casino, a new factory or a big box store out on the highway, locality after locality has followed the copycat logic of big project mania. However, successful economic development is rarely about the one big thing. More frequently, it is about lots of smaller things working synergistically together in a plan that makes sense. (McMahon 2019)

McMahon went on to point out the many challenges of the $21^{\text {st }}$ century including changes in climate, demographics, energy, technology, health care and consumer 
attitudes. He also stressed the importance of place in today's economy and highlighted the move from a traditional economic model which is product driven and cost sensitive to one which is knowledge driven and value sensitive. And what could be more relevant to libraries than that?

\section{Libraries and Sustainability}

Where, then, do libraries fit in? In recent years, spectacular new library buildings have grabbed the headlines and attracted public attention. These buildings are rightly proud of their sustainability credentials employing energy-saving approaches, sustainably sourced materials and approved fixtures and fittings. Nonetheless, new buildings inevitably make a demand on the environment and add additional strain on infrastructure. Two previous books in the IFLA Publications series look at green issues (Hauke, Latimer, and Werner 2013; Hauke, Charney, and Sahavirta 2018). Both focus on sustainable strategies and services in libraries rather than whole building recycling and a chapter in the 2013 work on sustainability as a tool to build community defines developing a green building as "the practice of creating structures and using processes that are environmentally responsible and resource-efficient throughout a building's life-cycle from site selection to design, through construction, operation, maintenance, renovation and deconstruction" (Genovese and Albanese 2013, 41). The definition is based on the premise of a new building. A later chapter on the second-hand library, however, foreshadows the growing interest in the reuse of existing buildings. The authors note that, "the transformation of an existing building with a prior non-library function into a library brings the challenge and the opportunity for sustainable thinking in library planning” (Hauke and Werner 2013). They cited examples including a 1950s textile printing factory, an EXPO pavilion, a railway station and a post office mailing centre. An extremely useful discussion on the factors to consider when transforming old buildings into libraries is given in the IFLA Guidelines (Romero 2007) and by the same author in this book.

Libraries, whether they serve universities and colleges or the general public, lie at the very heart of their communities. At the centre of almost every city, town or village is an historic building in need of a new use. Surely it is not beyond the bounds of imagination to bring these two things together. Libraries are increasingly becoming one-stop shops for many services and community activities and librarians have long held an enviable reputation for providing help, support and advice with the skills and knowledge to access a vast array of information in many different formats. By retaining and innovatively reusing existing buildings, 
libraries can highlight their cultural and social credentials; by aligning with their regional and local identity they can tap into vibrant communities who appreciate authenticity and create places where people want to be.

\section{Putting Theory into Practice}

The Society for the Protection of Ancient Buildings was founded in 1877 by William Morris, the English artist and craftsman. At the core of its manifesto was an emphasis on honesty in building fabric and respect for the layers of history; much of what Morris encouraged holds true today. When restoring and adapting an old building for a new use it is important that good new architecture complements and respects that which already exists. Successful schemes are those where the relationship between old and new elements is clearly understood and where there is a creative and imaginative approach as to how they will work together in the future.

Case studies of libraries which meet the above criteria and have breathed life into old buildings are presented in the second part of the book. In this more general overview a few examples, mainly from the UK and Ireland, which demonstrate the successful reincarnation of existing historic structures as libraries at the heart of their communities are briefly discussed. This can, of course, only be a selection and is based on the author's experiences as an inveterate visitor to library buildings old and new mainly as a member, and former Chair, of the IFLA Library Buildings and Equipment Section Standing Committee and as Secretary of the LIBER Architecture Group; a trawl through the literature will reveal many more projects that deserve to be lauded for their achievements. There are also many examples of existing libraries, such as the Weston Library at the University of Oxford, the Brynmor Jones Library at the University of Hull and several Carnegie libraries that have been skilfully refurbished but not being new uses they fall outside the scope of this book. Well worth a look, however.

\section{Ireland}

\section{Rush Library, County Dublin}

The problem of redundant churches has long been an issue in England but not so much in Ireland. Increasingly, however, churches are falling into disuse in 
Ireland and new uses are being sought for them. One such example is the $19^{\text {th }}$ century St Maur's Church in the small village of Rush in north County Dublin.

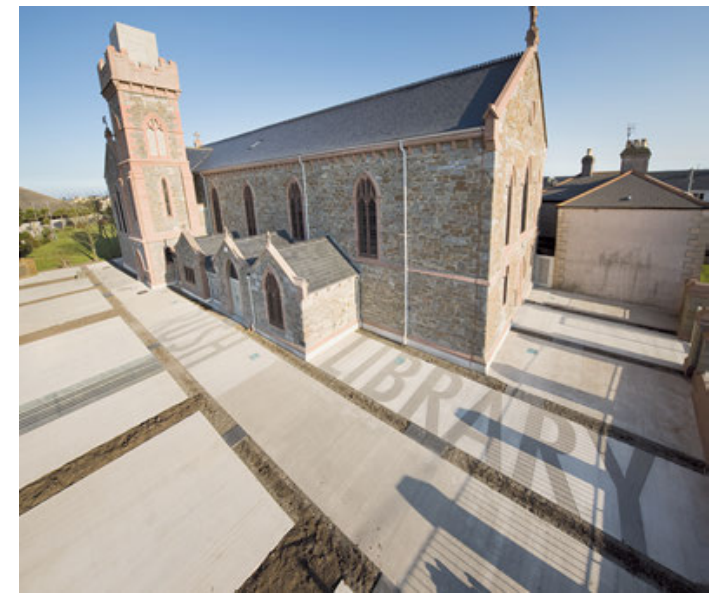

Fig. 1: Rush Library, Co Dublin: exterior. (c) Ros Kavanagh.

The architects McCullough Mulvin have a deep understanding of Irish architectural history and experience of designing library buildings, so they were the ideal practice to transform the church into a public library for the town. The church is beside the sea and the architects chose to make a distinct intervention which they describe as like a clump of seaweed in plan to reference its marine location. In reaching a resolution the architects and clients debated the function of libraries and explored what an appropriate $21^{\text {st }}$ century public space might be. They wanted to create a sense of place and forge a synthesis between old and new. Describing their approach to the project, the architects said:

And although great libraries use books to make the architecture, and books remain at the core of their meaning, libraries are not storehouses and must provide space for dreaming and thinking, and in modern libraries - discrete niches for a range of activities, for children, for older people, for groups, within a coherent whole. Increasingly (and especially in wet climates) they have a developing role as community public space - theatres of life and places for performance and observation. (McCullough and Ryan 2010, 14)

The dialogue between old and new is carefully nuanced so that glimpses of the old church blend with the new library requirements. The existing fabric is conserved and new spaces created so that old and new gain by proximity. Internally the intervention is quite major but externally it is minimal with the only significant change being a highly symbolic light box in the tower, a beacon of knowledge that can be seen far out to sea (Figure 1). The library entrance is through the 
old west door leading into the adult library and services desk, the children roam throughout the transepts and the chancel is now an art space with other activities such as function and lecture rooms in the side chapels and galleries (Figure 2). The churchyard has become a garden retaining the spirit of the graveyard while creating a playground and a protected public space for future generations (http:// mcculloughmulvin.com/projects/rush-library).

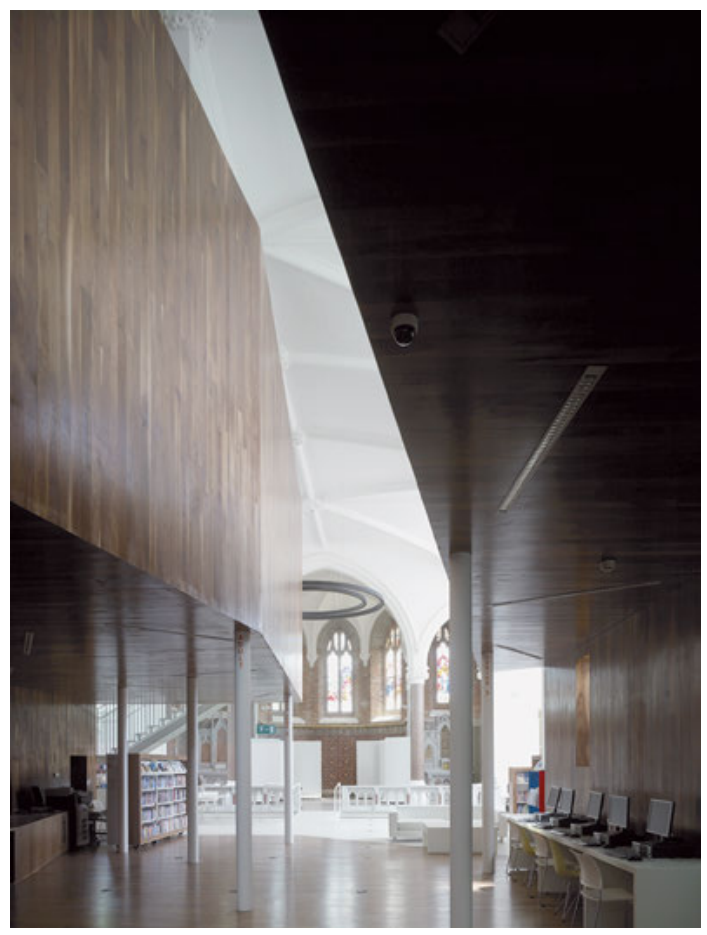

Fig. 2: Rush Library, Co Dublin: interior intervention. (c) Christian Richters.

McCullough Mulvin has also refurbished Carnegie libraries in Waterford and Blackrock, but these fall outside the scope of this book as the original buildings were designed to be libraries. However, their reuse of a terrace of typical Dublin Georgian houses as the new Dublin Dental School and Hospital which includes a new rooftop library picks up on the theme of converting spaces for a new use. Here a more radical approach has been taken to re-imagining the buildings. The rooftop is transformed by the addition of zinc pods containing a new library with light-well stalks forming niches and spaces around a corridor intervention linking the houses laterally. 


\section{Abbeyleix Library, County Laois}

Another Dublin architectural practice which has transformed an historic building into a library is De Blacam Meagher at Abbeyleix, County Laois. Originally built as a market house in 1836, it was remodelled in 1906 as a fire station with a library on the first floor. It has now been transformed into a branch library on three floors. The entrance at ground floor level leads to the borrower services desk and art spaces; the first floor has adult lending, IT, reprographics and the librarian's office; the children's library, storytelling and craft areas are on the second floor (https://laois.ie/departments/libraries/branch-libraries/abbeyleix/).

\section{Dublin City Library}

An exciting project which has been in the mix for some time is that for a new Dublin city library to provide an inspiring place in which all can learn, create and participate. The high-level vision is to deliver a cultural quarter for Dublin at Parnell Square anchored by a city library. The proposed development will encompass work to eight Grade I listed Georgian houses with a significant new build to the rear and the development of a new public plaza along Parnell Square North (Figure 3). Phase 1 of the project is at planning application stage in 2021 and will deliver the new build and one of the Georgian houses at 27 Parnell Square with an estimated completion date of 2023/24. Further phases will see the conservation and reuse of the remaining seven houses and the completion of the public plaza.

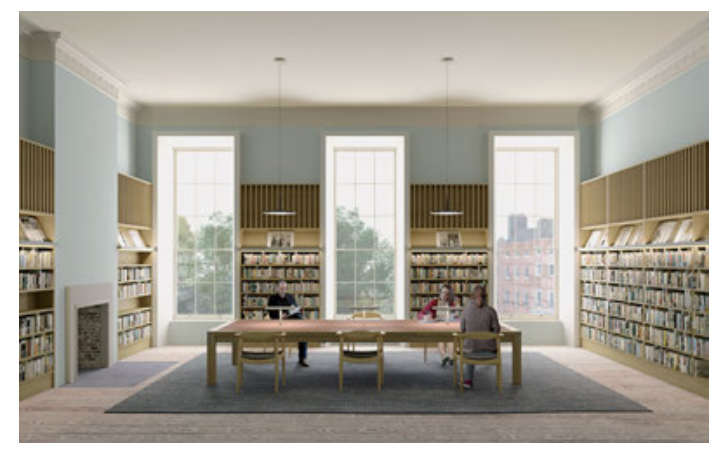

Fig. 3: Dublin City Library: proposed Georgian house interior. (C) Grafton Architects/Shaffrey Architects.

The brief for the new library is visionary and is based on seven key concepts: learning at the heart of the library; an inspiring place for children, young adults and families; a civic meeting place; a Storyhouse (literature centre); an 
Innovation Hub for business; a place for forging relationships, connections and collaboration; and a digital library (http://parnellsquare.ie/about-the-project/ city-library-services/). Its location beside the existing acclaimed Dublin City Gallery in Parnell Square, the earliest of the Georgian residential squares, is of great cultural and civic significance. Most exciting in the context of a book about breathing new life into old buildings is the overlapping of the historic and the contemporary. As Grafton's design statement states: "We overlap the contemporary with the $18^{\text {th }}$ century, the great Library Hall as public room overlaps with the generous, domestic intimacy of the houses" (Grafton Architects 2018, 13).

\section{Northern Ireland}

\section{Medical Library, Queen's University Belfast}

The main university library at Queen's University is a purpose-built state-ofthe-art $21^{\text {st }}$ century building but the Medical Library (https://www.qub.ac.uk/ directorates/InformationServices/TheLibrary/Locations/MedicalLibrary/) is in a late $19^{\text {th }}$ century High Victorian warehouse (Figure 4). The Mulhouse Works opened in 1881 for the weaving, bleaching, printing and warehousing of linen goods. It is an impressive structure in terms of its massing and scale built to demonstrate to the public the value of the enterprise within. The exterior is rich in detail with ornamented windows and an imposing entrance door.

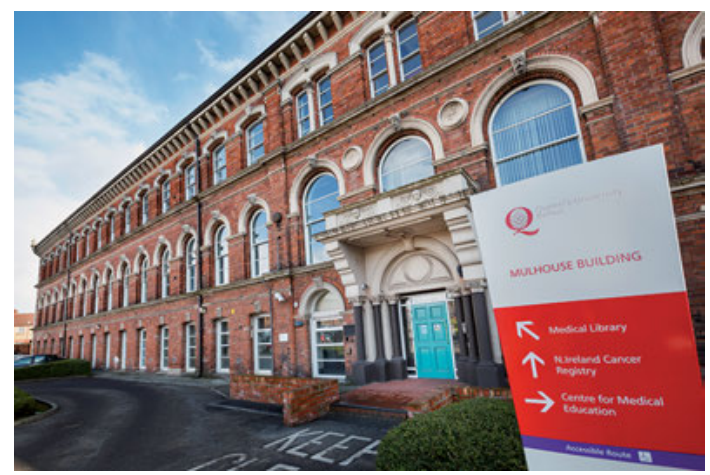

Fig. 4: Queen's University Medical Library. (c) Queen's University Belfast.

The weaving factory has been replaced by the library but the grand entrance door still welcomes the new users into the building. Inside, the building's original spatial configuration can be read despite subsequent internal partitioning par- 
ticularly in the library offices on the first floor, but much of its lavish detailing is still evident in the staircases, barley-sugar cast-iron columns and in wall and ceiling panelling. The building is of local historical interest, retaining much of its original fabric, and is of considerable social interest as it was once a major place of employment in the area. It is now a comparatively rare example of its type and has been converted very successfully to a practical library space with great character and ambience. Being a medical library much of the material is now available online with the historic collections shelved in compact storage at the back of the building and most of the space is devoted to zoned reading areas, group study rooms, teaching areas and library services.

Another remarkably successful example in Belfast is a school library created in a Greek Revival church building designed in 1833 by William Farrell. The building closed in 1993 and was burnt out in an arson attack in 1996 but restored as a library and IT centre for the Royal Belfast Academical Institution in 2002 (http:// rbai.org.uk/Page/RBAI-Library/4873/Index.html).

\section{England}

\section{Central St Martins Library, University of the Arts London}

Another former industrial building that is now used as a library is the grain store, designed in 1851 by Lewis Cubitt, which is part of the Granary complex behind St Pancras and Kings Cross railway stations overlooking the Regents Canal in London. The library serves Central St Martins which was formed in 1989 through the merger of Saint Martins College of Art and Central School of Arts and Crafts. The library, which opened in October 2011, is located on the second and third floors and totals $1,800 \mathrm{~m}^{2}$. Later a learning zone was created on the first floor and linked to the library by a staircase giving a total of $3,000 \mathrm{~m}^{2}$ across three floors. The result is a flagship space that students regard as being welcoming and inspirational. It provides improved access to hybrid collections in a high-quality library environment with flexible study spaces catering for a wide range of activities. The library also provides state-of-the-art, self-service and Wi-Fi technology and valuable display space for exhibitions. Stanton Williams, architects for the Central St Martins complex, are currently working on another library in an historical context, the Clermont-Ferrand Metropolitan Area Library. 


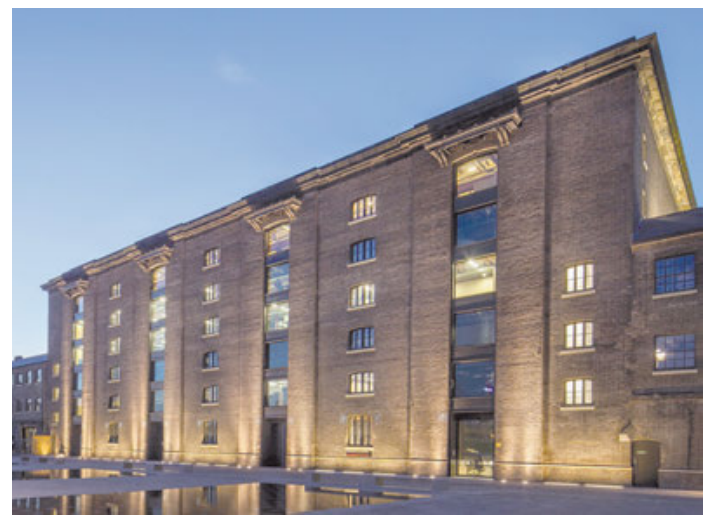

Fig. 5: Central St Martins, University of the Arts London. (c) John Sturrock.

Pat Christie, the former Director of Libraries and Academic Support Services at University of the Arts London (UAL) has commented on the importance of the library as place underpinning the student experience and satisfaction levels at UAL. It is a place for inspiration as well as information, and a place for creative practice as well as scholarly research. Christie is realistic about the restrictions of locating a library in $19^{\text {th }}$ century listed building with solid walls and low ceilings, however, and cites environmental management, IT infrastructure and flexibility as major challenges. Despite the challenges, the success of the library is indisputable and the decision to preserve and celebrate the original features of the Granary Building fully justified particularly in the context of a creative institution (Figure 5). There has been a massive increase in usage levels and feedback has been overwhelmingly positive. It is a stunning building which works well and has the wow factor in abundance (https://www.arts.ac.uk/colleges/central-saint-martins/student-lifeat-csm/facilities/general/library).

\section{The University of Lincoln Library}

The University of Lincoln's award-winning library is housed in the old Great Central Goods and Grain Warehouse built in 1907 and abandoned in 1998. The building is strategically sited in the heart of Lincoln next to the historic waterfront, an area revitalised by the growth of the university. It was sensitively restored in 2004 and is now a highly popular, fully functioning library with four floors and a mezzanine floor to give extra space; a variety of seating areas; meeting rooms; and IT labs. A key feature of the brief was to encapsulate a sense of interaction between the public and the student population (https://www.visitlincoln.com/ things-to-do/university-of-lincoln-library). 


\section{The Storyhouse, Chester}

Another building type which lends itself to new uses is the cinema. A successful example of a cinema transformed into a library and much more can be found in Chester, a historic city in northwest England, founded as a Roman fortress in the $1^{\text {st }}$ century CE. The Art Deco Odeon cinema, designed by Robert Bullivant with Harry Weedon who was responsible for all the Odeons at the time, opened in the town in October 1936. In deference to its historic context close to the cathedral and Victorian town hall, it was designed in red brick rather than faced with ceramic tiles as was the case in other cities. The building was Grade II listed in 1989 but after many years as a cinema it closed in 2007 and remained unused until the Storyhouse project came to fruition in 2017. The $£ 37$ million project transformed the 1930s cinema into a theatre, cinema and library building with restaurants and bars and has won many awards including one for the best reuse of an existing building. It has brought a much-loved building back into use and transformed Chester's Northgate area.

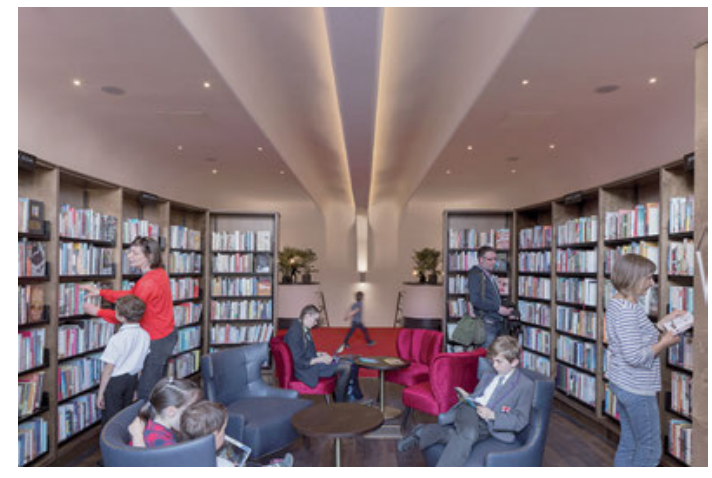

Fig. 6: Storyhouse library reading room, Chester. (c) Peter Cook.

Storyhouse aims to connect people through storytelling and the library is central to that vision. It weaves its way across all three floors providing reading rooms, meeting and study spaces, over $700 \mathrm{~m}$ of shelving (Figure 6) and an exciting and creative children's library with opportunities for arts and crafts as well as storytelling in the Den and Storytelling Room. The library's website describes it as, "an inspirational place for adults and children alike, to keep, make, and share great stories and ideas." Demco Interiors were the consultants on the interior furnishings, shelving and fittings and they have cleverly echoed the Art Deco style by housing the steel Cantilibra shelving within a dark stained and lacquered plywood frame. The joinery used throughout the building also picks up on the Art Deco theme (https://www.storyhouse.com/about/the-building). 
There has been some adverse comment about noise and cramped conditions, but this is far outweighed by recognition of the role Storyhouse has played in reviving library use in Chester and beyond. It is an attractive and inspiring space and the advantages of co-location, a recurrent theme in reusing historic buildings, include the opportunity to hold joint events and keep the library open for longer hours. As well as a vast increase in individual user numbers, there has been a significant uptake from community groups who use Storyhouse as their base. The Library Planet website description sums up the atmosphere of the building perfectly:

A place full of art, performance and wonder but where, magically-enough, the library collection itself - rather than finding itself lost in all of the excitement - now permeates every nook, corridor and corner. The cookbook section covers the restaurant walls, old card catalogue cabinets repurposed as tables sit in the study areas and quotes from poet Lemn Sissay are quite literally writ large on the walls in playful, bold typefaces (https://libraryplanet. net/2019/09/04/the-storyhouse-chester-england-once-upon-a-time-there-lived-a-library/).

\section{Some Churches, a Brewery and a Swimming Pool}

The former All Saints parish church in Oxford is a very important early Palladian building probably designed by Dean Henry Aldrich in 1701-10 and restored in the late $19^{\text {th }}$ century in various phases with the hand of the famed architect Nicholas Hawksmoor also in evidence. The handsome church became redundant in 1971 and was offered to the College where it found a new use as the library for Lincoln College Oxford in 1975. It is not a recent project but it is certainly an inspirational example. The only major change to the interior was the raising of the original floor to provide space for a lower reading room and the Senior Library containing a collection of old and rare books was located beneath the east end of the church in a fine room with $18^{\text {th }}$ century panelling. The upper reading room, the Cohen Room, has an impressive, plastered ceiling, decorated with the shields of the original major subscribers to the rebuilding. In addition, it must be one of the few examples of a library with a full peal of eight bells, and these are still rung regularly! (https://lincoln.ox.ac.uk/student-life/learning-at-lincoln/library-andresources).

Another, more recent, restored church is the listed St Mary's at Lichfield in Staffordshire. Library design firm, Opening the Book, worked with local architects BHB Architects, who have significant experience in conservation work, to revitalise the space as the new town library on the ground floor and an events space and gallery on the first floor. The challenge was to create an attractive, functional 
space while retaining the listed elements in the historic building. A great deal of thought went into the colour scheme and detailing to complement the existing stonework and architectural features. That the challenge was met can be seen in the vastly increased visitor and borrowing figures (https://www.openingthebook. com/library-design/case-studies/church-public-library-refurbishment).

One other project that can stand as an exemplar is the 2019 transformation of the brewhouse of the former Redruth Brewery, which stands at the heart of the Cornish Mining World Heritage Site, into an archive and library. Kresen Kernow houses the largest collection of information on Cornwall's people, places, history and culture from 1150. As well as holding some 1.5 million records, it has research rooms, exhibition spaces, learning rooms and digitisation and preservation suites. The very experienced architectural practice, Purcell Architects, led the design team for the whole complex with Demco Interiors working on the furnishing and library shelving for the library and archive areas. The result is a design which respects the heritage of the original building while providing a modern library and archive service. It achieves the holy grail of blending old and new in a sympathetic way (https://kresenkernow.org/).

In Warwickshire in the historic town of Royal Leamington Spa there is even a swimming pool that has been converted into a library. Library users are delighted to see the building back in use and fondly remember looking up at the roof while doing backstroke (https://www.royal-leamington-spa.co.uk/ leamington-spa-library/).

\section{Scotland}

\section{The Olympia Cinema, Glasgow}

In Scotland, another example of a cinema reused as a library can be found in Glasgow. The Olympia cinema at Bridgeton Cross was a much-loved landmark building which opened in 1911 and served its community until the mid-1990s when it fell into disrepair. Responding to local wishes, the Olympia was bought in 2009 as part of a wider development and work began in 2011. Unlike other examples cited in this chapter much of the structure was demolished to accommodate multiple new uses, including the library and café on the ground floor but the B-listed façade was retained, which was crucial to the character of the area and sense of place. The Olympia, sensitively combining old and new under the skilful direction of Page and Park Architects, who worked on the restoration of the world-famous Charles Rennie Mackintosh building at the Glasgow School of 
Art, was opened to great acclaim in 2012. The public library has an extensive collection in all media, PCs, community spaces, a children's area and Scotland's first Médiathèque. The number of users has tripled and the impact on the surrounding area has been immense (https://www.glasgowlife.org.uk/libraries/venues/ bridgeton-library).

\section{The Courthouse, Grantown-on-Spey}

The other Scottish examples include a courthouse and another church. Grantown-on-Spey is a small town in the north of Scotland. Its new library is in the handsome, historic courthouse conveniently sited in the busy town square. The vision for the library, which is co-located with the Highland Council's Service Point, was to provide an up-to-date community hub alongside traditional library services. Thanks to its ideal location, historic connotations and its stylish interiors, created by library designers The Design Concept, the library has proved to be very popular both with locals and visitors to the Cairngorm National Park (https://www.highlifehighland.com/libraries/grantown-on-spey-library/).

\section{Martyrs Kirk, St Andrews}

Further south on the east coast in the historic university town of St Andrews is a postgraduate library located in the old Martyrs Kirk designed by Gillespie and Scott in 1928. The transformation into a library in 2014 was again carried out by

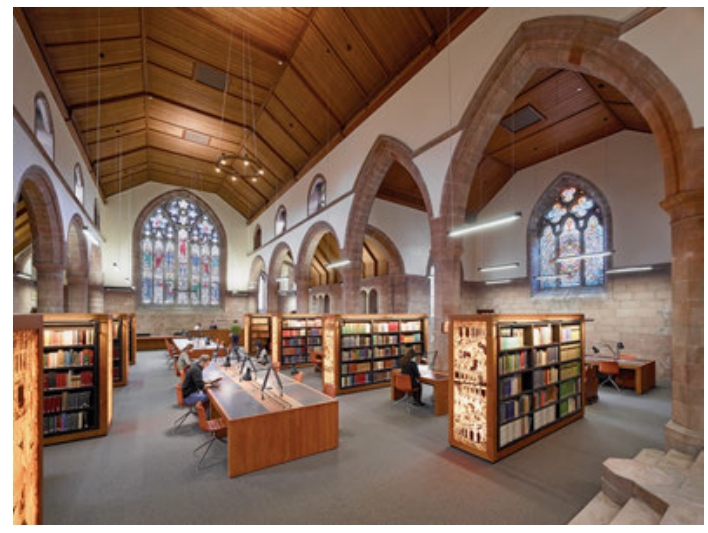

Fig. 7: Martyrs Kirk postgraduate library, St Andrews University. (C) Andrew Lee. 
Page and Park with great sensitivity and respect for the original architecture. Client and architect alike were clear that this should not just be a case of putting a reading room into the empty volume of an old church; instead, using crafted desks and shelving carefully placed between the arches, they have created an intimacy within the greater volume and married the academic use with the ecclesiastical nature of the architecture (Figure 7). Further accommodation has been provided in the side halls with similar care and consideration (https://www. st-andrews.ac.uk/library/contact/departmental/martyrs/).

\section{Wales}

\section{Holyhead Market Hall Library and History Centre}

From Wales is another example of a market hall reuse. The Grade II listed market hall in Holyhead was built in 1855 but closed in 2000 and lay derelict until purchased under a Compulsory Purchase Order (CPO), a legal directive allowing certain bodies to obtain property without the owner's consent, in 2015. Work to transform it into a library finally started in early 2016 with the refurbishment of the original iron gates. The building opened to the public again in September 2019 as the Holyhead Library complete with a local history centre, a teen-focused area, meeting rooms, a commercial area and a coffee shop, event space and proposals for an extensive heritage interpretation in development. Again, architects Purcell and interior library designers Demco were involved in the project as at Redruth and again the goal was to create a functional, attractive interior that remained sympathetic to the heritage of the original building. An added challenge was the raked flagstone floor in the foyer and local history area which required bespoke furniture and shelving to take account of the change in floor levels (https://www. anglesey.gov.uk/en/Residents/Libraries/Find-your-local-library/Holyhead-Library.aspx).

Another Welsh project in the wings is the restoration of the Grade II listed Maesteg Town Hall in Bridgend. The plan is to turn the former indoor market on the lower ground floor into a modern library. It is another multi-use project which will include a heritage and volunteering centre, a café and workspaces (https:// www.maestegtownhall.com/). 


\section{Some Examples from Around the World}

Old buildings reused successfully as libraries can be found all around the world. It has been a privilege to visit many excellent examples in the role of library consultant but in this short chapter it is possible to mention only a couple of the most inspirational.

\section{The University of Luxembourg Learning Centre, Belval Campus}

The Luxembourg Learning Centre (LLC) (Figure 8) designed by Valentiny HVP is a spectacular example of an existing structure transformed into an innovative and inspiring learning centre for the students at the University of Luxembourg. It is part of an extremely ambitious project to regenerate the industrial site at Belval following on from a prolonged recession in the steel industry in the 1980s-90s culminating in the closure of the last of the blast furnaces in 1997. The Fonds Belval was created to construct the Cité des Sciences in 2002 and it was decided to make Belval the main campus of the newly formed University of Luxembourg in 2005.

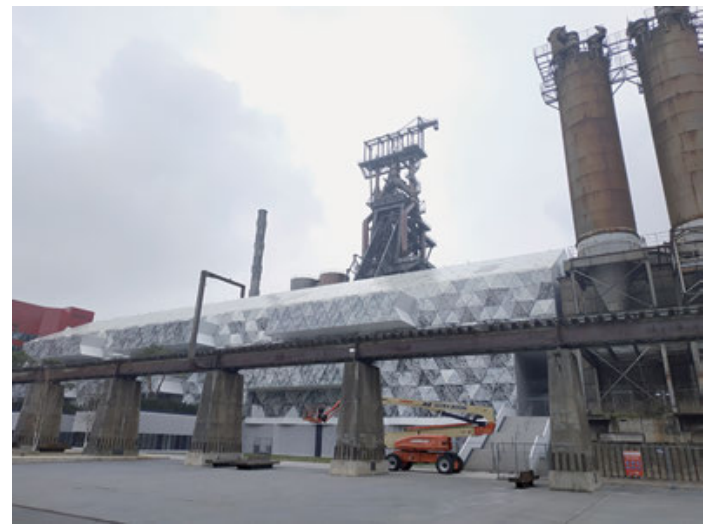

Fig. 8: University of Luxembourg Learning Centre exterior, Belval. (c) Ignasi Bonet.

The LLC, which opened in 2018, was cleverly integrated into the steel structure of the old Möllerei beside the two remaining blast furnaces. The façade is both beautiful and functional; it echoes the design of the old factory windows and regulates the flow of light into the building. From the exterior it appears opaque but from inside it is permeable and creates an atmosphere of openness and character. The interior design continues the feeling of spaciousness with floating platforms on thin slanting columns and a prominent main staircase connecting the spaces from top to bottom (Figure 9). The interior is punctuated with colour thanks to 
the brilliantly illuminated shelving and the bright colour-coded furniture distinguishing the different levels of the library. Acoustic panels and sound-reducing carpets help to combat noise levels. The LLC has over 1,000 seats including individual, group and meeting room spaces. It has $10,700 \mathrm{~m}$ of shelving as well as a café, conference centre and three garden areas at the top.

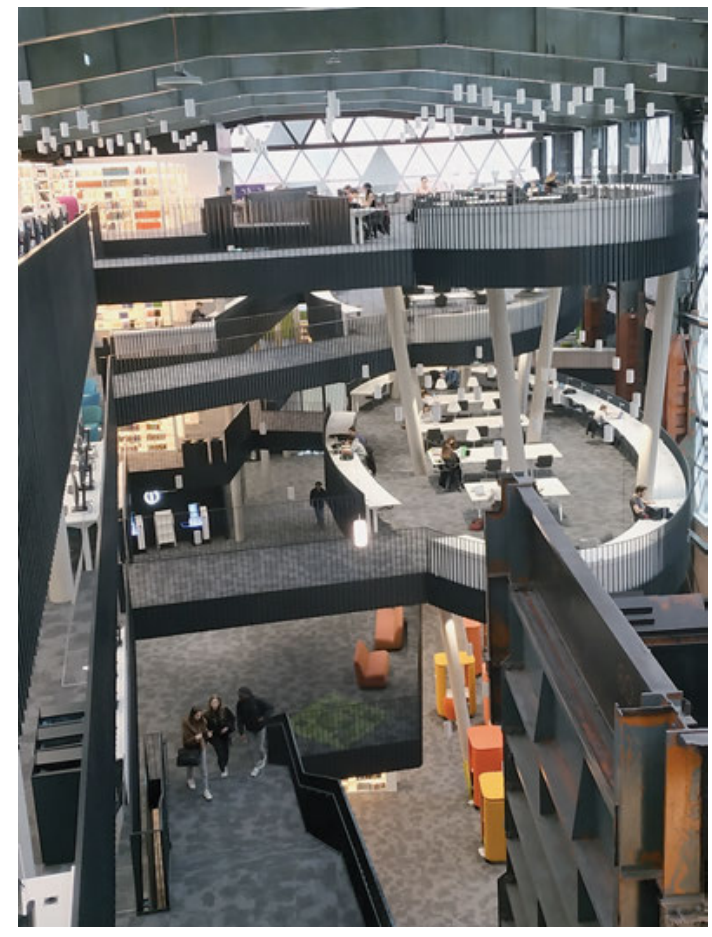

Fig. 9: University of Luxembourg Learning Centre interior, Belval. (c) Ignasi Bonet.

It is a stunning building that captures the essence of the old whilst creating a bang up-to-the-minute learning centre for a $21^{\text {st }}$ century university (https://llc. uni.lu/en/).

\section{HTWG Library, Konstanz, Germany}

One of the most atmospheric buildings visited is the library of the HTWG University of Applied Sciences in Konstanz (Figure 10). The library is located on the edge of Konstanz's old town and has stunning views of the lake and the Alps. The listed building was originally an abattoir built between 1877 and 1879 continuing in use until 1991. Work on transforming it into a library began in 1994 and it 
opened in 1997 mainly supporting engineering and computer science students but also including material on business administration, design and architecture. The main structural elements were retained with the interior stripped out. The stunning main hall with its beautifully detailed cast-iron columns, elegant ironwork and heavy timber beams provides delightful workspaces and houses the main collection. The interior design and furnishings took their cue from the wood and steel of the original building. Study places can also be found in the side wings and journals reading room and a new area was created in 2017 to provide additional seating. Basements were created under the wings to provide space for toilets and building services.

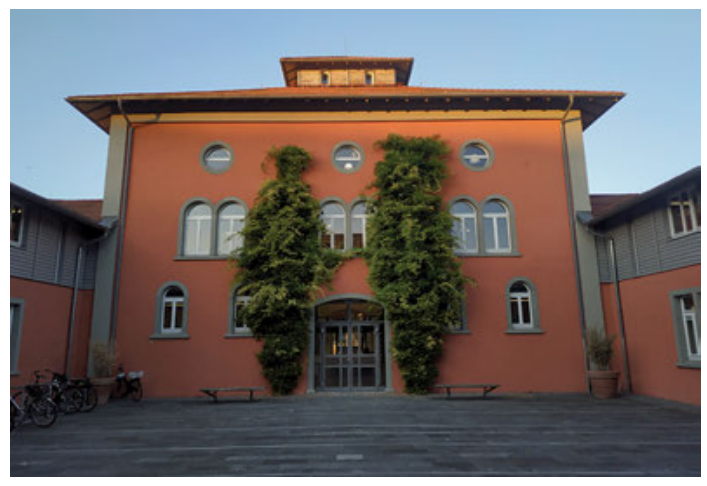

Fig. 10: Abattoir building, HTWG University of Applied Sciences, Konstanz. () Ignasi Bonet.

Although most of the material is available online, visitor numbers are continually increasing which is not surprising given the atmospheric, and functional, surroundings (Figure 11). One of the slight disadvantages of working within the framework of the existing building was that the front and back offices are further apart than ideally desirable but this is a small price to pay for such a wonderfully evocative library (https://www.htwg-konstanz.de/en/the-university/facilities/ library/start/).

Having described the grain store that is now the library for Central St Martins in London, it is perhaps pertinent to draw attention to another similar example, the Zwickau City Library in central Germany. Built in 1481 as a communal grain store, it opened as a storehouse of knowledge in 2014. It is one of the largest libraries in Saxony and houses a collection of approximately 15,000 items, a music library, a children's library, a computer area and public meeting space (https:// www.stadtbibliothek-zwickau.de/).

It was a privilege to join an august body of architects and librarians to judge the competition for the conversion of the courthouse in Macao into the new central library. This splendid building in the centre of Macao was built in 1951 as 


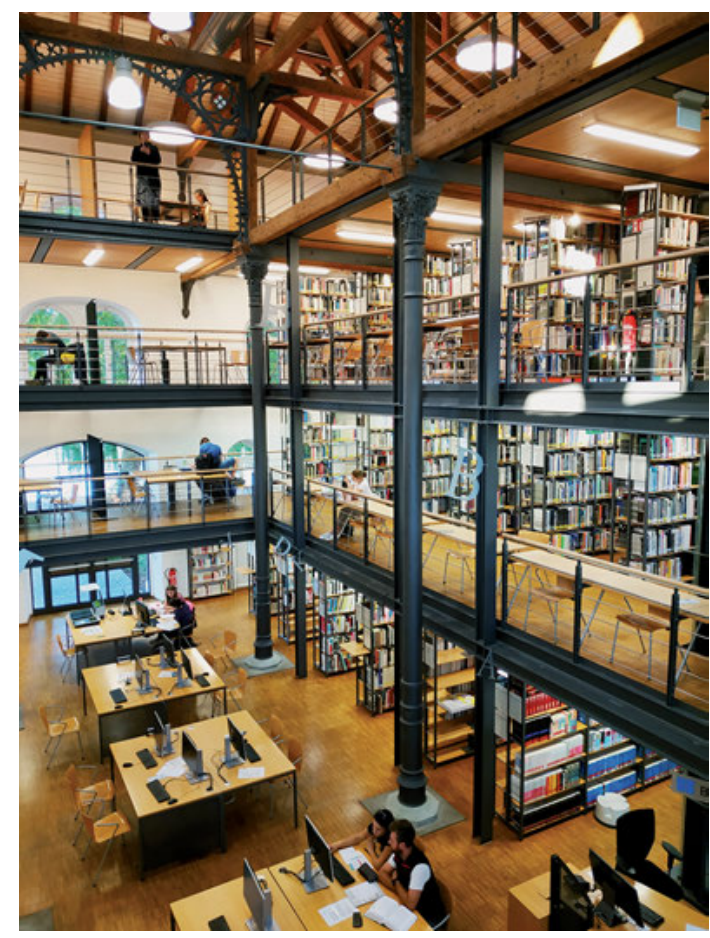

Fig. 11: Library interior, HTWG University of Applied Sciences, Konstanz. () Ignasi Bonet.

offices for the Portuguese government including the Judiciary Police headquarters and then became a courthouse. It is a designated structure of importance. While the project has recently been abandoned, it is an interesting example of a reuse proposal (https://www.macaubusiness.com/new-central-library-projectat-old-court-building-abandoned/) and pleasingly plans for a spectacular new Central Library in Macau have just been announced.

\section{Conclusion}

Examples abound of old buildings which have been successfully reborn as new modern libraries. Some work is better than others but that is the case with libraries built from scratch. Historic buildings in particular have to be updated sensitively, simultaneously respecting key architectural features and enabling the provision of modern-day services. There will always be debate about the balance between purist conservation and modern intervention and between authenticity and functional requirements and each case needs to be looked at individually. 
New and existing spaces should speak to, and complement, each other. A library in a listed $15^{\text {th }}$ century church poses different challenges from one in a 1950s office block. In any library project whether it be new build, refurbishment or reuse, there will be constant dialogue and modification as part of the design process.

That there are challenges with reuse of buildings cannot be denied. The holy grail of flexibility and futureproofing can be harder to achieve but is by no means impossible; environmental management and acoustics need to be carefully considered; IT provision with ubiquitous Wi-Fi may require creative solutions but modern technology is well able to cope. And the advantages are legion. Historic buildings tend to have character and ambience, be centrally located, come with a ready-made identity as loved landmarks and have impeccable sustainability credentials.

Finally, in the context of sustainability, reuse and transformation should surely be the default position and demolition and new build the option of last resort.

\section{References}

Baker-Brown, Duncan. 2019. “Architects Have Declared, but What Do We Do Next?" RIBA Journal, September 12, 2019. https://www.ribaj.com/intelligence/sustainability-circulareconomy-construction-reusing-recyling-duncan-baker-brown

Cooke, Rachel. 2019. "We Should Cherish the Places that are a Feast for the Eyes and Feed the Soul." The Guardian, December 21, 2019: 57. https://www.theguardian.com/ commentisfree/2019/dec/21/we-should-cherish-places-that-are-a-feast-for-the-eyes-andfeed-the-soul

English Heritage. 2004. Heritage Counts 2004: The State of England's Historic Environment. London: English Heritage.

Genovese, Peter, and Patricia Albanese. 2013. "Sustainability Can Serve as a Tool to Build Community." In The Green Library = Die Grüne Bibliothek: The Challenge of Environmental Sustainability (IFLA Publication, 161); edited by Petra Hauke, Karen Latimer, and Klaus U. Werner, 39-64. Berlin/Boston: De Gruyter. https://edoc.hu-berlin.de/handle/18452/2946 Grafton Architects/Shaffrey Architects. 2018. Dublin City Library/Parnell Square Cultural Quarter: Architects Design Statement. Dublin: Grafton Architects/Shaffrey Architects. http://parnellsquare.ie/wp-content/uploads/2018/10/PSCQ-Architects-Design-Statement. pdf

Hauke, Petra, Karen Latimer, and Klaus U. Werner, eds. 2013. The Green Library= Die Grüne Bibliothek: The Challenge of Environmental Sustainability (IFLA Publication, 161). Berlin/ Boston: De Gruyter. https://edoc.hu-berlin.de/handle/18452/60

Hauke, Petra, Madeleine Charney, and Harri Sahavirta, eds. 2018. Going Green: Implementing Sustainable Strategies in Libraries Around the World (IFLA Publication, 177). Berlin/ Boston: De Gruyter.

Hauke, Petra, and Klaus U. Werner. 2013. "The Second-hand Library - a Way of Reducing the Ecological Footprint." In The Green Library = Die Grüne Bibliothek: The Challenge of 
Environmental Sustainability (IFLA Publication, 161); edited by Petra Hauke, Karen Latimer, and Klaus U. Werner, 175-93. Berlin/Boston: De Gruyter. https://edoc.hu-berlin.de/ bitstream/handle/18452/2954/175.pdf?sequence=1

Jacobs, Jane. 1961. The Death and Life of Great American Cities. London: Jonathan Cape.

McCullough, Niall, and Raymond Ryan. 2010. Rush Library: McCullough Mulvin Architects. Dublin: Anne Street Press. http://mcculloughmulvin.com/projects/rush-library McMahon, Ed. 2019. “Invest in a Great Place for Prosperity." Virginia Town \& City (November): 18-20. https://frazierassociates.com/wp-content/uploads/2019/12/article-invest-in-agreat-place-2019.pdf

Romero, Santi. 2007. "Renovating Historic Buildings.” In IFLA Library Building Guidelines: Developments \& Reflections, edited by Karen Latimer and Helen Niegaard, 219-28. München: Saur.

Tapper, James. 2019. "Experts Call for Ban on Glass Skyscrapers to Save Energy in Climate Crisis.” The Observer, July 28, 2019. https://www.theguardian.com/environment/2019/ $\mathrm{jul} / 28 /$ ban-all-glass-skscrapers-to-save-energy-in-climate-crisis

Watts, Jonathan. 2019. “Concrete: The Most Destructive Material on Earth.” The Guardian, February 25, 2019. https://www.theguardian.com/cities/2019/feb/25/concrete-the-mostdestructive-material-on-earth 
